\title{
A Novel Approach of Controlling the Solar PV Integrated Hybrid Multilevel Inverter
}

\author{
Sunita Kumari, Sudhir Y. Kumar
}

Electrical Engineering Dept, CET, Mody University, India

\begin{tabular}{l}
\hline \hline Article Info \\
\hline Article history: \\
Received Nov 27, 2017 \\
Revised Jan 22, 2018 \\
Accepted May 6, 2018 \\
\hline
\end{tabular}

\section{Keyword:}

Boost converter

Cascaded 13-level inverter

PID controller

SMC controller

Solar PV cell

\begin{abstract}
The part of renewable energy systems like solar photovoltaic (PV) and wind power generation (WPG) is playing an energetic role in energy production. The power electronics technology growths have directed to the progresses in the solar power generation and solar PV sources have the potential to progress one of the key providers to the upcoming electricity. Lower voltage rating of solar PV systems requires a high voltage progress converter for parts grid associating with a DC-AC inverter. The solar energy acquired from the solar panel varies with times and solar irradiation. The boost DC/DC converter is used to sustain the constant output voltage achieved from the solar panel using MPPT algorithm and is operated according to the requirement. A 1- $\Phi$ cascade 13-level inverter is used to produce 13-level output voltage from the DC supply voltage achieved from PV panels. It offers better-quality sinusoidal output voltage and current waveforms and lower total harmonic distortion. In this paper, the proposed model is designed and the results are verified through simulation using MATLAB/SIMULINK tools.
\end{abstract}

Copyright $\odot 2018$ Institute of Advanced Engineering and Science. All rights reserved.

\section{Corresponding Author:}

Sunita Kumari,

Electrical Engineering Dept, CET, Mody University, +919251929126, Lakshmangarh, India

Email: sunita.electrical@gmail.com

\section{INTRODUCTION}

Nowadays, the utilization of renewable energy is more advantageous in both economically and environmentally [1-2]. Amongst several categories of renewable resources for energy like solar and wind energy have become very common and challenging owed to its modern technology. Currently, solar PV sources are used in various advantages for example free from pollution. So, the demand of solar electric energy has grown-up continuously over the last 20 years by $20-25 \%$ per annum [3]. The photovoltaic cell inverter is used to change DC power/voltage into AC power/voltage acquired from PV modules to be fed into the load or load may be DC or AC drives [3]. Therefore, improvement in current and voltage output waveforms and performance of the traditional inverter decreases its corresponding harmonic content created by switching action of the inverter [6]. In latest years, multilevel cascade inverters have developed new attractive features for scientists and constructors due to their benefits compare to traditional 3-level pulse width-modulated (PWM) inverters. These types of inverters proposal improved output voltage and current waveforms, lower electromagnetic interference (EMI), lesser alter size lower total harmonic distortion (THD) [7]. The most important working topologies in multilevel inverter (MLI) are cascade H-bridge (CHB), diodeclamped (NPC) and flying-capacitor (FC) inverter. All three converter topologies have the potential for application in medium and high voltages. Multilevel inverters contain selection of power electronic semiconductor devices and capacitor voltage sources, the output voltage of which generate through stepped voltage waveforms. By growing the numeral of stages in the inverter, the output voltages have more stages producing a staircase waveform which has a reduced harmonic distortion. But, a great number of stages raise 
the controller complexity and presents voltage discrepancy problems. The FC topology is equivalent to the NPC with difference that the clamping diodes are exchanged by flying capacitors and CHBs inverters are classified by way of series connection of two or more 1- $\Phi$ bridge inverters. High switching frequency and fundamental switching frequency PWM methods are used to operate the cascaded multilevel inverters because it has higher efficiency and lower switching loss. In the CHB MLI, each level needs a separate DC source and for each DC source a PV cell or battery is to be coupled. As compare to other two, CHB MLI needs the minimum numeral of components and requires the prospective for utility interface applications as of its competences for applying modulation and soft switching techniques [7-8].

\section{PROPOSED CONCEPT}

The proposed circuit as shown in figure 1 consists of the $1-\Phi$ cascade 13 -level inverter fed from solar cell boost converter using PID/SMC controller. Maximum power point tracking (MPPT) is employed in solar array power structure through direct control method. To track the maximum power point tracking used the incremental conductance algorithm as it implements superior control below fast altering atmospheric condition and boost converter is used to increase (step up) the voltage using a transformer less circuit. We use 24 switches in 6 DC sources to get required 13-level output voltage and current and to decrease the harmonics in multilevel inverter [4]. Boost converter (DC-DC) is used to adjust and to achieve the preferred input voltage and after that the DC voltage source is exchanged by renewable resources of energy such as solar panels to get desired DC voltage to load.

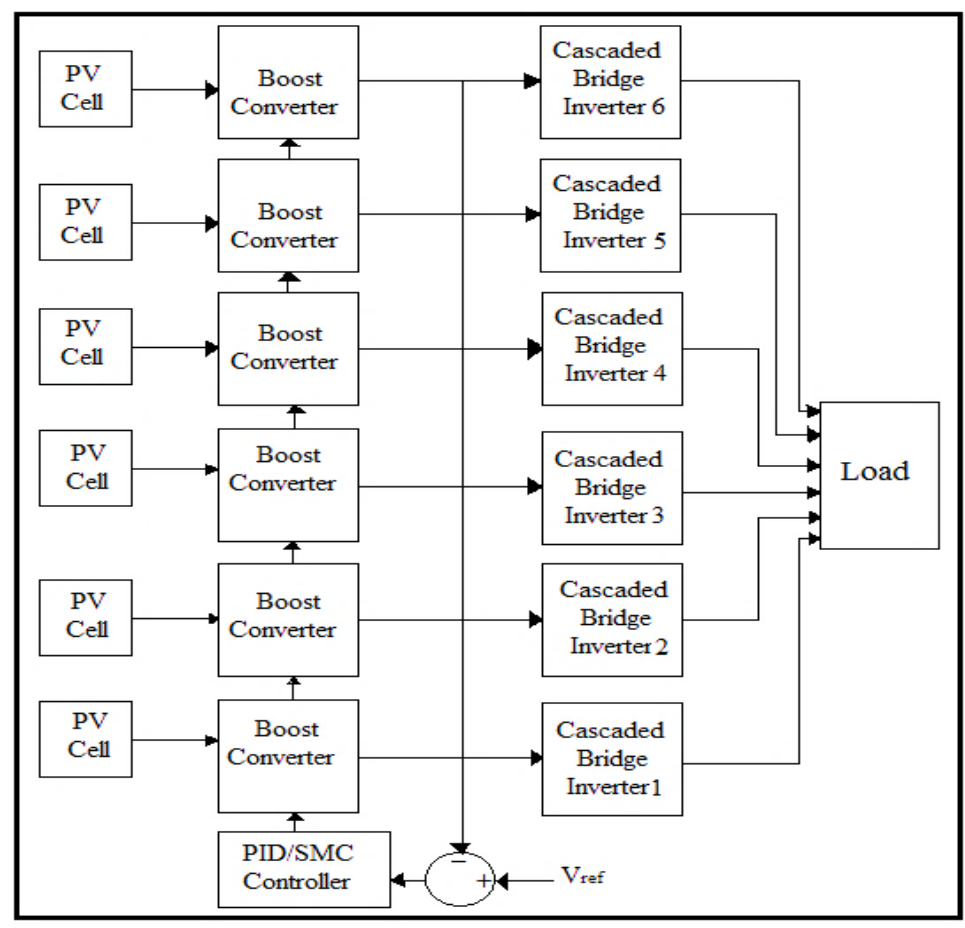

Figure 1. General configuration of proposed circuit

\section{METHODOLOGY}

The building block of a solar panel in solar cell is a device that serves to transform solar radiation into DC current to produce electric power. The energy conversion occurs from solar radiation to DC power on the principle of photovoltaic effect in semiconductor materials. The model as shown in figure 2 is established with the effects of solar radiation and temperature changes using basic circuit equations of the photovoltaic (PV) solar cells and it can be described using a photocurrent source, diode, series resistance (Rs) and the parallel resistance (Rsh). 


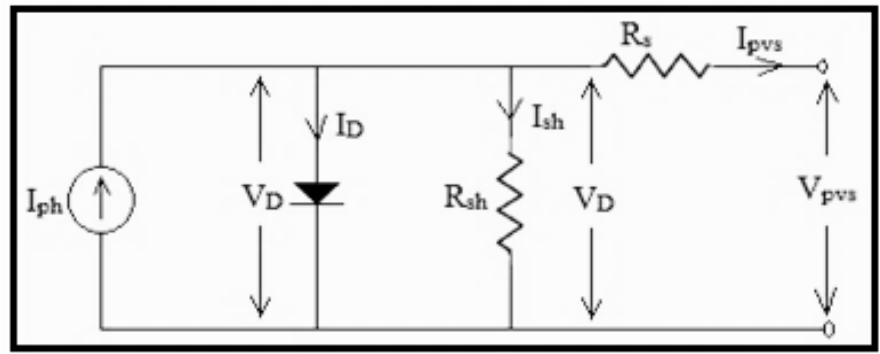

Figure 2. Solar PV cell equivalent circuit model [4-5]

$$
\begin{aligned}
& I_{p v s}=N_{P} I_{p h}-N_{P} I_{D}-I_{s h} \\
& I_{D}=I_{o}\left[\exp \left(\frac{q V_{D}}{n K T}\right)-1\right] \\
& I_{s h}=\frac{V_{D}}{R_{s h}} \\
& V_{D}=\left(I_{p v s} R_{s}+\frac{V_{p v s}}{N_{s}}\right) / N_{P}
\end{aligned}
$$

Equation (2), (3) and (4) put in equation (1)

$$
\begin{aligned}
& I_{p v s}=N_{P} I_{p h}-N_{P} * I_{o}\left[\exp \left(\frac{q V_{D}}{n K T}\right)-1\right]-\left(\frac{N_{P}}{N_{s}} V_{p v s}+I_{p v s} R_{s}\right) / R_{s h} \\
& V_{p v s}=\frac{N_{s} K T}{q} \\
& I_{o}=I_{o n}\left(\frac{T}{T_{n}}\right)^{3} \exp \left[\frac{q E_{g}}{n K}\left(\frac{1}{T_{n}}-\frac{1}{T}\right)\right] \\
& I_{o n}=\frac{I_{s c n}}{\exp \left(V_{o c n} / n V_{T n}\right)-1}
\end{aligned}
$$

Where,

$\mathrm{I}_{\mathrm{pvs}}$ : Cell output current (A)

$\mathrm{I}_{\mathrm{D}}$ : Diode current $(\mathrm{A})$

$\mathrm{q}$ : Electron charge $\left(1.602 \times 10^{-19} \mathrm{C}\right)$

$\mathrm{n}$ : The diode ideality factor

$\mathrm{I}_{\mathrm{ph}}$ : Photovoltaic current (A)

$\mathrm{R}_{\mathrm{Sh}}$ : Cell shunt resistance $(\Omega)$

$\mathrm{N}_{\mathrm{P}}$ : No. of parallel cells
$\mathrm{V}_{\mathrm{pvs}}$ : Cell output voltage (V)

$\mathrm{I}_{0}$ : The saturated reverse current $(\mathrm{A})$

$\mathrm{K}$ : Constant of Boltzmann $\left(1.38 \times 10^{-23} \mathrm{~J} /{ }^{\circ} \mathrm{K}\right)$

$\mathrm{T}$ : Operating temperature of Cell $\left({ }^{\mathrm{o}} \mathrm{K}\right)$

$\mathrm{R}_{\mathrm{S}}$ : Cell series resistance $(\Omega)$

$\mathrm{N}_{\mathrm{S}}:$ No. of series cells

$\mathrm{T}_{\mathrm{n}}$ : Cell reference temperature $\left({ }^{\mathrm{o}} \mathrm{K}\right)$ 


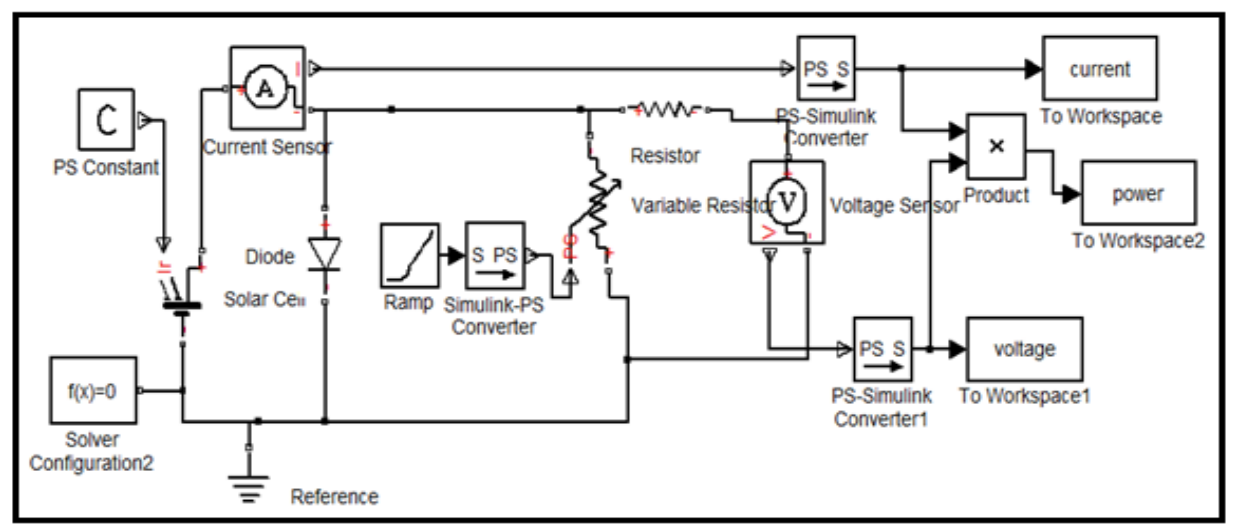

Figure 3. Simulink model of solar pv cell

Here, we have considered number of cells in series and parallel plates as per the requirement of boost converter input DC voltage. The output currents and voltages of the PV array will follow the changes in temperature and solar radiation levels of solar plates. The operating temperature of solar cell changes for finding the new photocurrent and new output voltage values when we change the radiation levels and ambient temperature. The equivalent electric circuits is possible to draw the solar PV cell characteristics. Figure 3 is given the model of solar cell in Matlab/Simulink software. The solar PV module has nonlinear characteristic and it is essential to model for the design and simulation of maximum power point tracking (MPPT) for the system curves like power-voltage (P-V) and current-voltage (I-V) characteristics are drawn according to values changes of the solar radiation and temperature and it is observed in figures 4, 5, 6 and 7 . The simulation results for solar cell in $\mathrm{I}-\mathrm{V}$ and $\mathrm{P}-\mathrm{V}$ characteristics showed that the maximum power point achieved as of PV modules below normal working conditions.

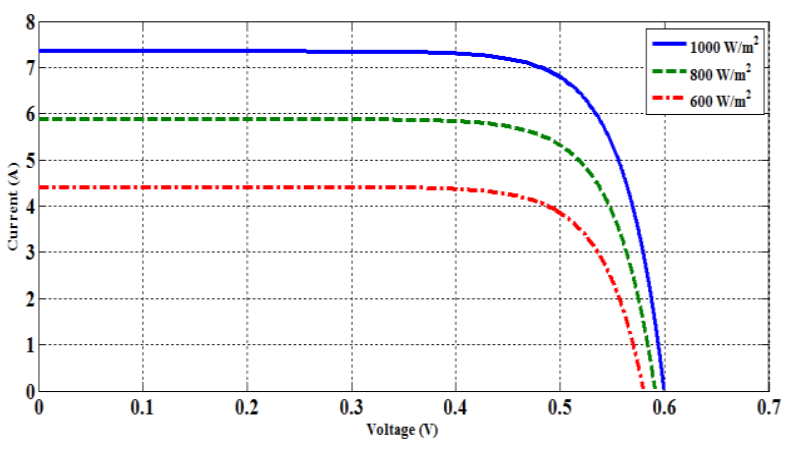

Figure 4. I-V characteristics at irradiance variation

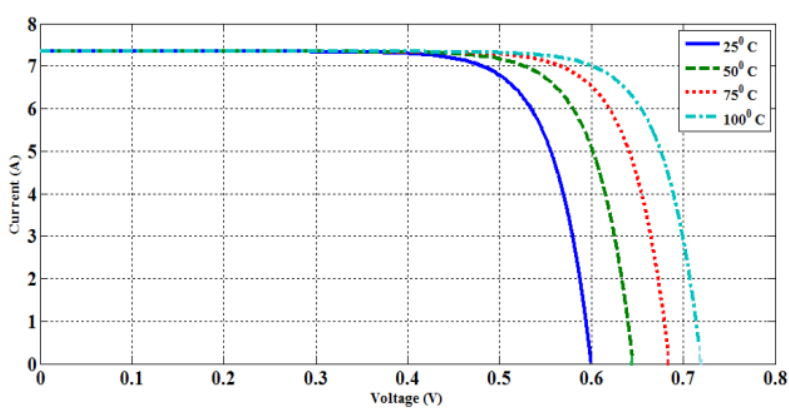

Figure 6. I-V characteristics at temperature variation

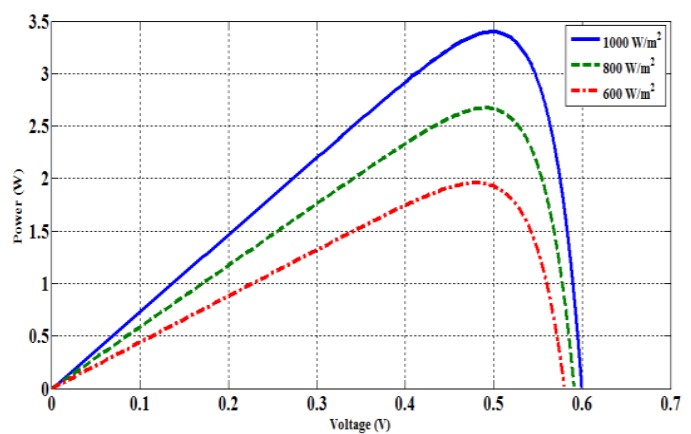

Figure 5. P-V characteristics at radiance variation

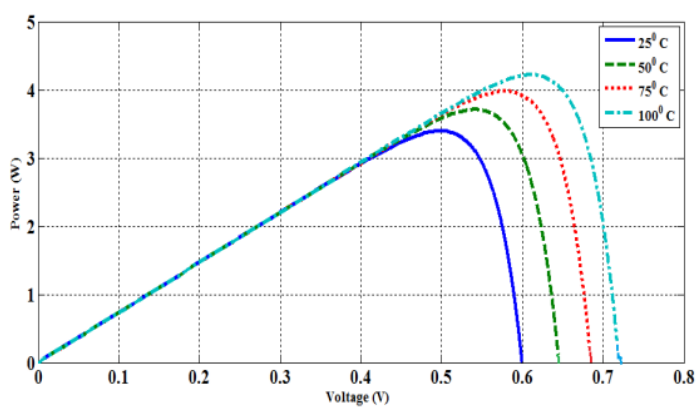

Figure 7. P-V characteristics at temperature variation 


\section{1-Ф CASCADED MULTILEVEL INVERTER INTERFACE WITH BOOST CONVERTER AND SOLAR PANEL}

The concept of STATCOM based multilevel power inverter is the combination to make a new power inverter in replacement of the conventional power inverters for grid connection system without battery which possesses capability of flexible AC transmission system (FACTs) in the proposed control strategy with no additional cost [10]. Static synchronous compensator (STATCOM) is the part of FACTs devices. So, the FACT is a technology which provides a methodology for the utilities to minimize the gap between the thermal limits and stability, to enhance capability of transmission lines and to improve reliability of grid [9, 11-13]. Subsequently, power can come from solar panel for the boost converter and it is used to step up the voltage or step down the current from its input supply voltage to its load output voltage or vice-versa. The boost converter as shown in figure 9 is having 2 semiconductors i.e. a diode and an insulated gate bipolar transistor (IGBT), energy storage element like capacitor and an inductor or the grouping of these two elements and it is also called a class of switched mode power supply (SMPS)

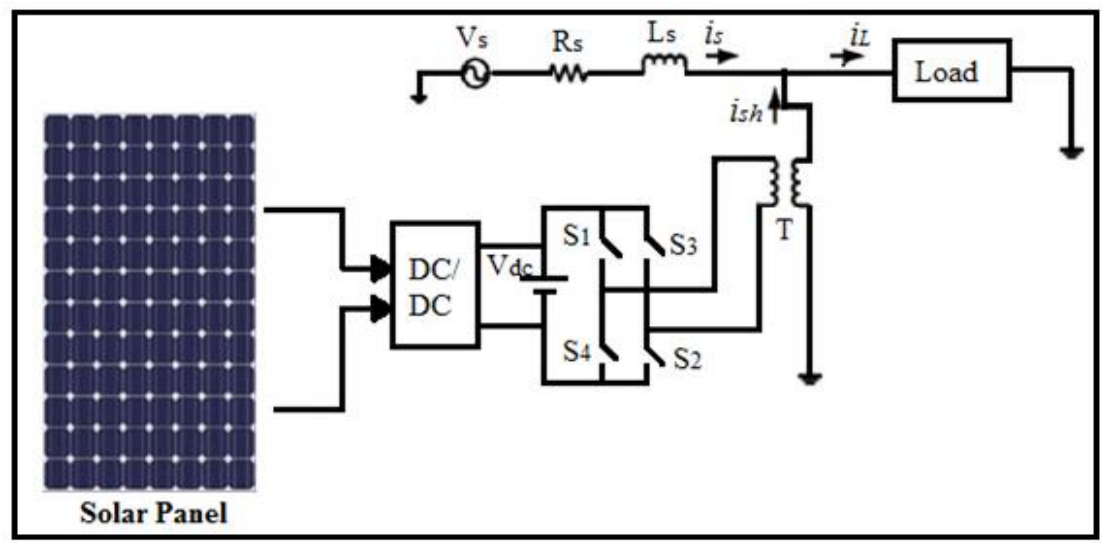

Figure 8. STATCOM based solar energy conversion system

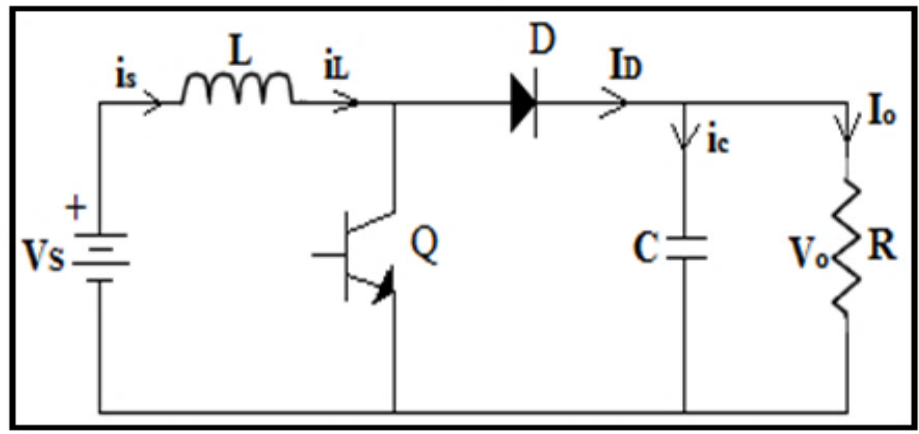

Figure 9. Block diagram of boost converter [22]

Two loop controls i.e. an outer voltage control loop and an inner current control loop is used in this study. Here, the voltage loop controller is a linear type proportional integral derivative (PID) controller. Therefore, the output voltage is much lower than that of the the rate of current signal, a sliding mode controller (SMC) is used in the inner current loop and is shown in figure 9 [14-21].

$$
\begin{aligned}
& \text { Put } x_{1}=i_{L}=i_{s} \quad \& \quad x_{2}=V_{0}=V_{c} \\
& \left.\qquad \begin{array}{l}
\dot{x}_{1} \\
\dot{x}_{2}
\end{array}\right]=\left[\begin{array}{cc}
0 & -(1-u) \frac{1}{L} \\
(1-u) \frac{1}{C} & -\frac{1}{R C}
\end{array}\right]\left[\begin{array}{l}
x_{1} \\
x_{2}
\end{array}\right]+\left[\begin{array}{l}
\frac{1}{L} \\
0
\end{array}\right] V_{s}
\end{aligned}
$$


where, input control $u \rightarrow$ position of switch function $\operatorname{set}\{0 ; 1\}$

In sliding mode control (SMC), the state vector $\mathrm{x}$ paths a chosen trajectory $\mathrm{x}^{*}$ in the existence of external disturbance and model uncertainties for finding control input $\mathrm{u}$. Then the form of sliding surface:

$$
S(x)=x-x^{*}
$$

If the initial condition $\mathrm{S}(0)=0$ is not satisfied then the tracking can only be achieved after a transient phase i.e. called reaching mode/phase and the state variable error is defined by equation (10).

$$
S=x_{1}-x^{*}{ }_{1}=0
$$

It proceeds that the control technique forces the system to improve on the sliding surface. The value of reference $x^{*}{ }_{1}$ is derived within the controller from the linear output voltage controller. To impose sliding mode in the manifold $S=0$, the corresponding control signal for the ideal switch in fig. 10, the equation (11) is

$$
u=1 / 2 *[1-\operatorname{sign}(S)]
$$

Since the state trajectory of the system is focused to the sliding surface $S=0$, a slide above it and this is done with a proper design of control law by the reaching condition:

$$
\mathrm{SS} \cdot 0
$$

The steady state values of state variables overlap with the corresponding reference values and they are constant then, $x^{*}{ }_{1}=0$, replacing equation (10) in equation (12) and solving it at $x_{2}>V_{s}$.

Figure 10 shows the Simulink model of solar cell DC/DC boost converter which receives power from the solar cell with PID and SMC controllers and then it is fed to the 1- $\Phi$ cascaded 13-level inverter with grid connected i.e. shown in figure 11 [24]. The proposed 1- $\Phi$ hybrid STATCOM based multilevel inverter with solar PV panel is simulated for 13-level output voltage waveform using MATLB/Simulink as shown in figure 12 and combined figure 10,11 and developed figure 12. The hybrid multilevel inverter has isolated DC sources. In this simulation, for each DC source the separate solar PV panel with boost converter is considered.

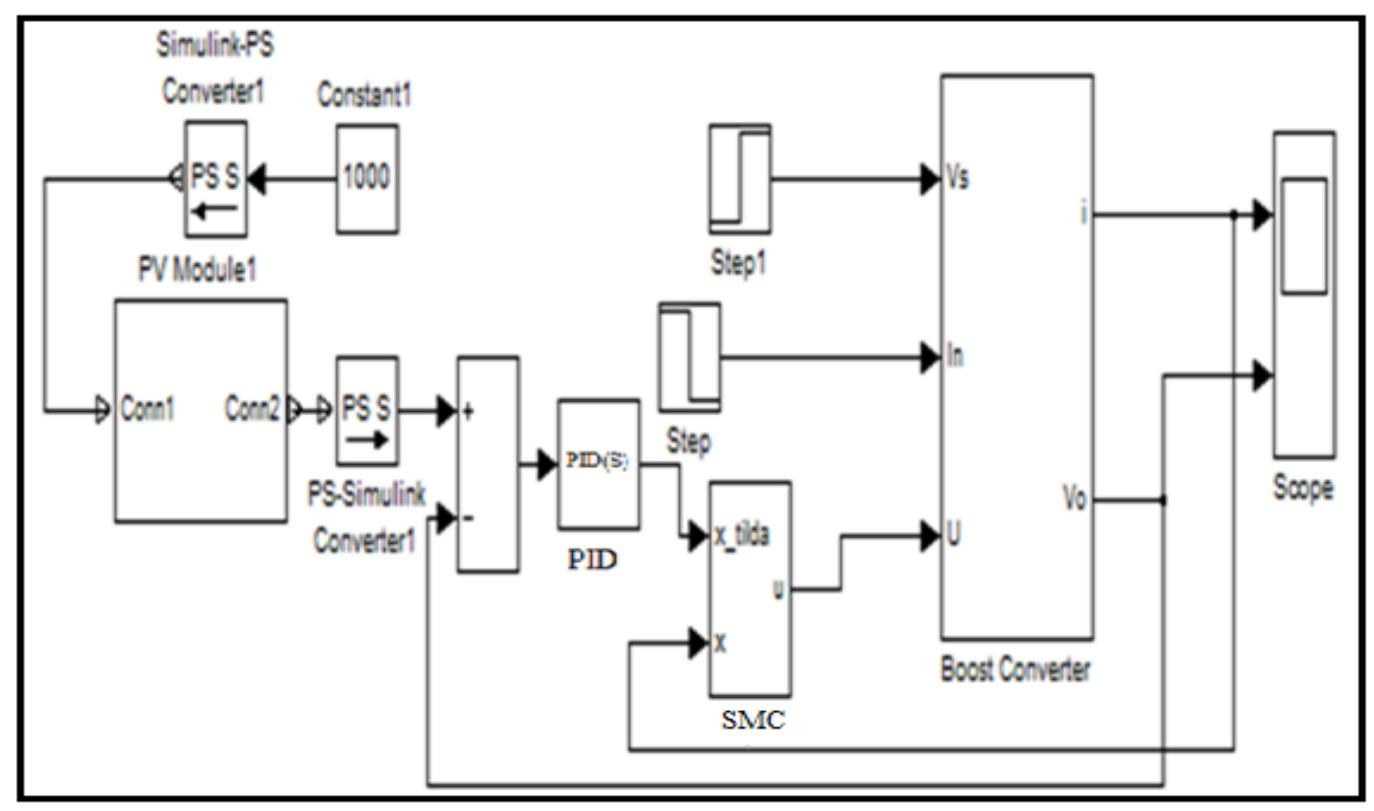

Figure 10. Simulink model of grid connected 1-ф cascaded 13-level inverter 


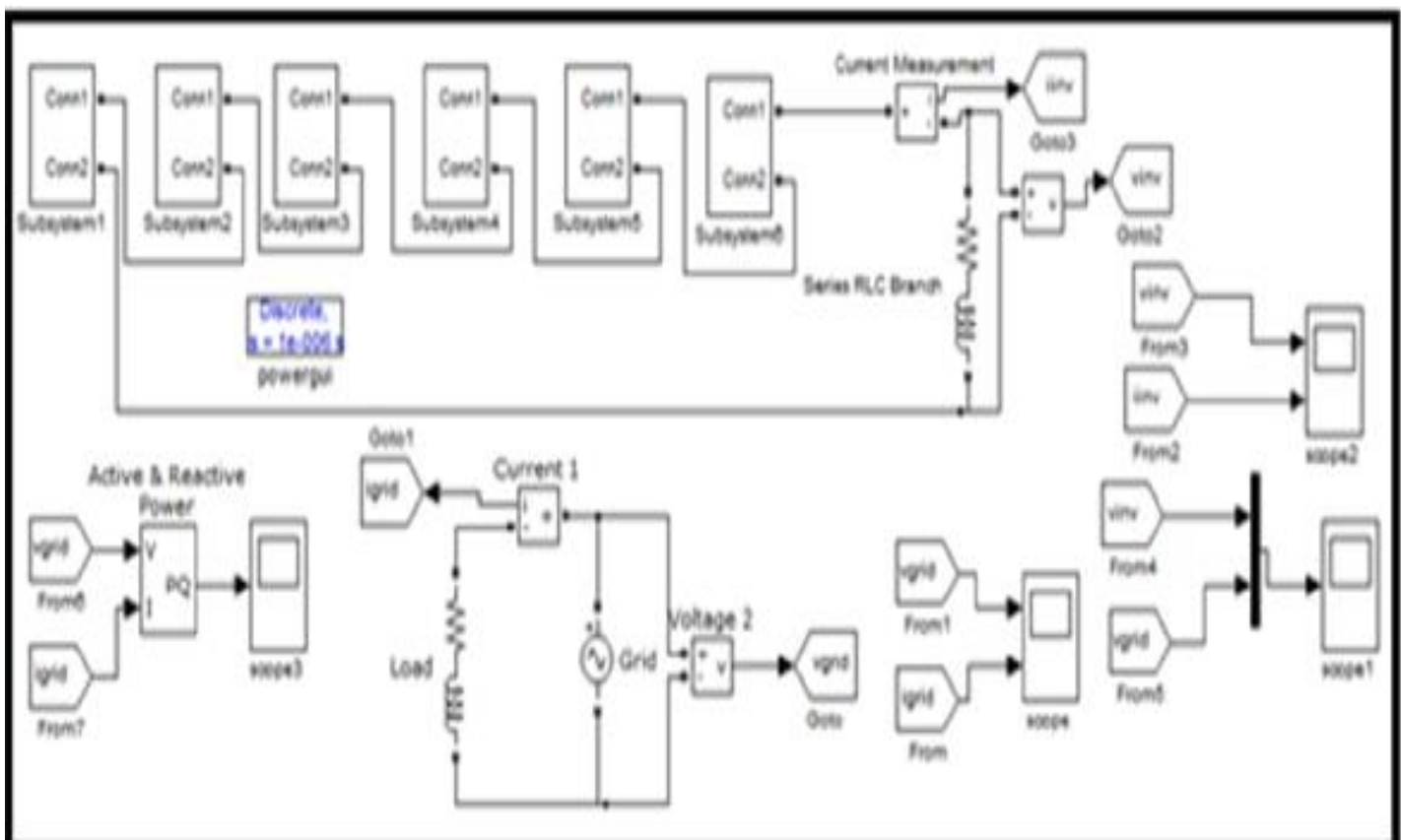

Figure 11: Simulink Model of Grid Connected 1-Ф Cascaded 13-level Inverter

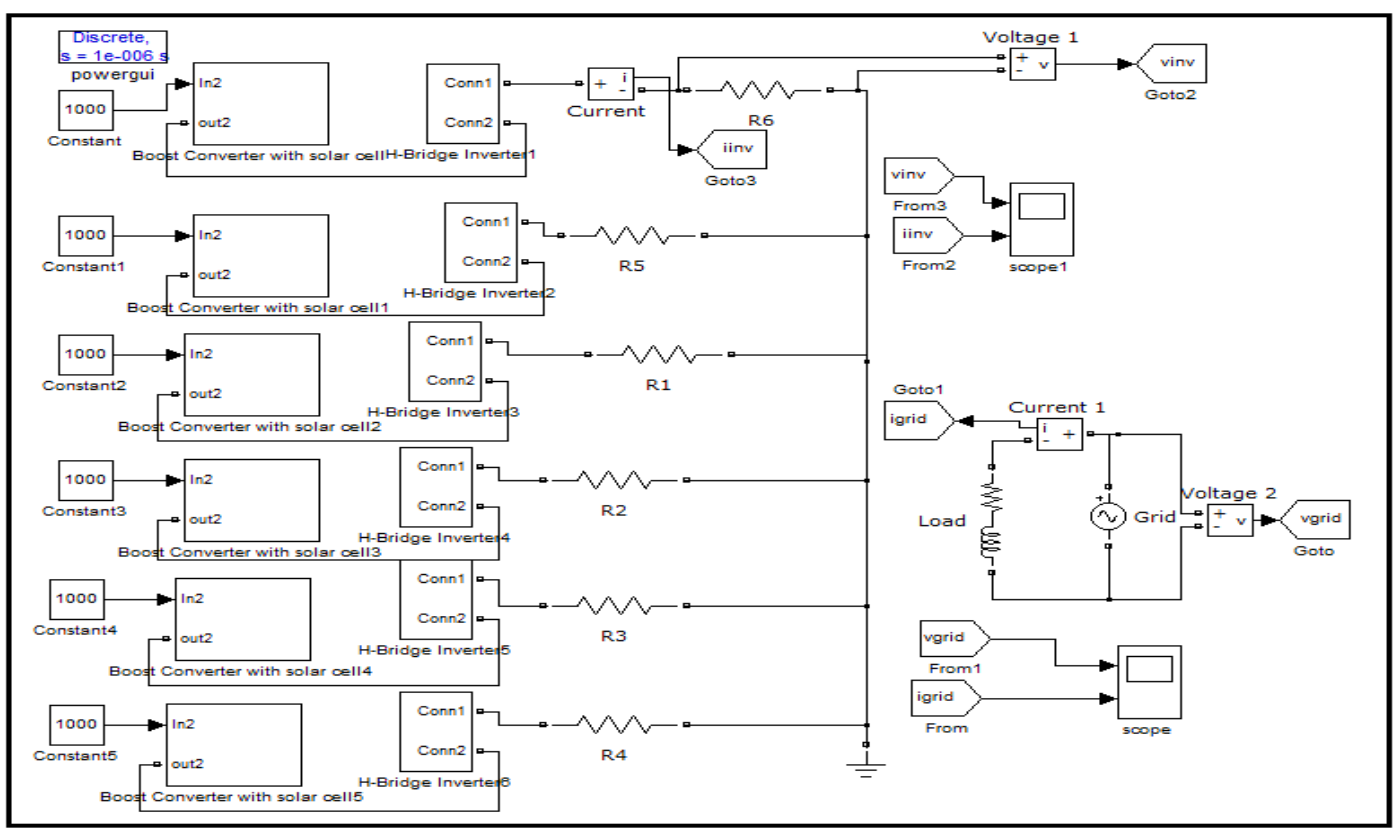

Figure 12. Simulink model of 1-ф hybrid STATCOM based cascaded 13-level inverter fed from solar cell boost converter (Balanced Load)

Table 1. Design Parameters for Solar Panel

\begin{tabular}{lc}
\hline \multicolumn{1}{c}{ Parameters } & Values \\
\hline No. of parallel cells & 90 \\
No. of Series cells & 90 \\
Solar Radiation & $1000 \mathrm{~W} / \mathrm{m} 2$ \\
Operating temperature of Cell & $300 \mathrm{oK}$ \\
Input Voltage for Boost Converter, Vin & $27 \mathrm{~V}$ (nearest of 25V) \\
(Output of the Solar Panel) & \\
\hline
\end{tabular}




\section{SIMULATION RESULTS AND DISCUSSION}

The models are accomplished on a distinctive DC/DC boost converter circuit for finding $100 \mathrm{~V}$ according to parameter variations in DC/DC boost converter circuit. Figure 13 showed the desired output voltage $(100 \mathrm{~V})$ with ripple of the given circuit from the input voltage $(25 \mathrm{~V})$ obtained from the solar panel. It is well known that hybrid controller is observed as a robust feedback control method w.r.t. coordinated unmodelled plant parameter variations and external perturbation signals..

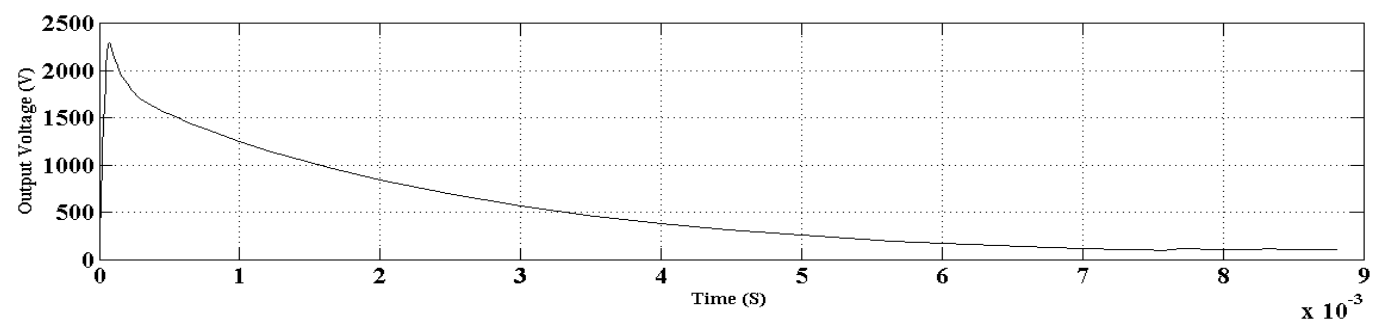

Figure 13. Output voltage of solar cell boost converter with hybrid controller

Figure 14 conclude that the CHB MLI voltage $(6 * 100=600 \mathrm{~V})$ is greater than system (grid) supply voltage (max. voltage $=220 \mathrm{~V}$ ). Then, CHB MLI circuit will work as a supply than system voltage to the load and measured the active $(1555.87 \mathrm{~W})$ and reactive power (155.59VAR) as shown in figure 15.

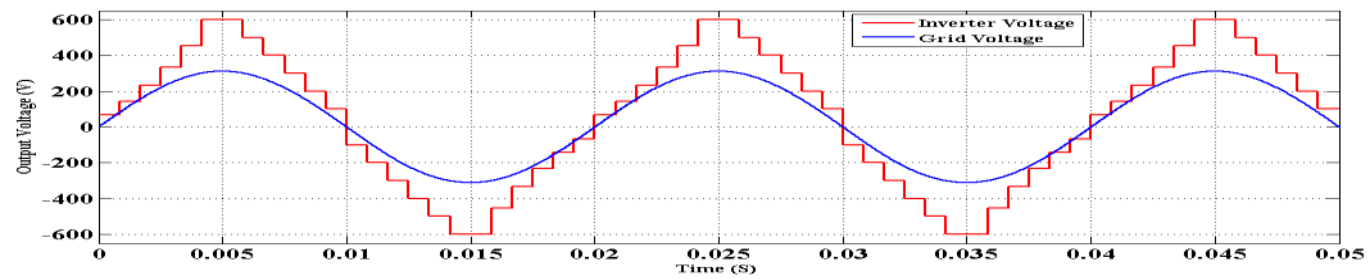

Figure 14. Output voltage of grid connected 1-ф cascaded 13-level inverter

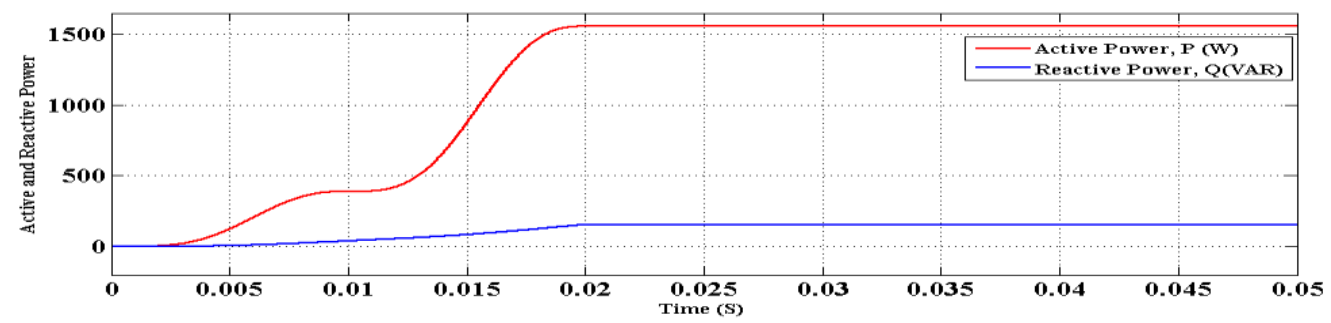

Figure 15. Measurement of active and reactive power for 1- $\phi$ cascaded 13-level inverter fed from solar cell boost converter

\section{CONCLUSION}

This paper discussed about the simulation of solar PV cell STATCOM based cascaded 13-level inverter intermediate with DC/DC boost converter. The DC/DC boost converter is permitted to work in continuous mode. The sequence in switching performance of multilevel inverter is decided by a PWM generator which uses a PIDPWM and SMCPWM techniques. It could be possible to minimize total harmonic distortion, to achieve at a low cost, high efficiency over a wide power range, to develop interfacing in power electronic for the highest projected solar panel rating, to optimize the energy conversion and transmission and to have a high reliability. It is noted that the designed boost converter and cascade 13-level inverter are able to maintain the DC and AC voltage at the desired value respectively from the output voltage waveforms and the results given in this paper can also be extended with experimental studies 


\section{REFERENCES}

[1] N. Prabaharan, K. Palanisamy, "A single phase grid connected hybrid multilevel inverter for interfacing photovoltaic system", Applied Energy Symposium and Forum, REM2016: Renewable Energy Integration with Mini/Microgrid, 19-21 April, Maldives, Energy Procedia 102, pp. 250-255, 2016.

[2] Habbati Bellia, Ramdani Youcef and Moulay Fatima, "A Detailed Modeling of Photovoltaic Module using MATLAB", National Research Institute of Astronomy and Geophysics (NRIAG) Journal of Astronomy and Geophysics Vol. 3, pp. 53-61, May 2014.

[3] Vikas Khare, Savita Nema and Prashant Baredar, "Status of Solar Wind Renewable Energy in India", Renewable and Sustainable Energy Reviews, SciVerse ScienceDirect, Vol. 27, pp. 1-10, Nov. 2013.

[4] J. Yuncong, J. A. A. Qahouq, and M. Orabi, "Matlab/Pspice hybrid simulation modeling of solar PV cell/module," in Applied Power Electronics Conference and Exposition (APEC), 2011 Twenty-Sixth Annual IEEE, pp. 12441250, 2011.

[5] M.B. Eteiba, E.T. El Shenawy, J.H. Shazly and A.Z. Hafez, "A Photovoltaic (Cell, Module, Array) Simulation and Monitoring Model using MATLAB ${ }^{8} /$ GUI Interface”, International Journal of Computer Applications, Vol. 69, No.6, May 2013.

[6] S. A. Bashi, N. F. Mailah, M. Z. Kadir and K.H. Leong, "Generation of Triggering Signals for Multilevel Converter", Euro Journals Publishing, Inc. 2008.

[7] Sunita Kumari, Sudhir Y Kumar, "Design and Control of Multilevel Inverter Topologies for Industrial Applications", International Journal of Mechanical Engineering and Technology (IJMET), (ISSN: 0976-6359) Volume 8, Issue 6, pp. 107-116, June 2017.

[8] Jeffrey Ewanchuk, John Salmon, and Behzad Vafakhah, "A Five-/Nine-Level Twelve-Switch Neutral-PointClamped Inverter for High-Speed Electric Drives”, IEEE Transactions on Industry Applications, Vol. 47, No. 5, pp. 2145-2153, Sept./Oct. 2011.

[9] Laszio Gyugyi, "Application Characteristics of Converter-Based FACTS Controllers", IEEE Siemens Power Transmission \& Distribution, 2000.

[10] Sunita Kumari, Sudhir Y Kumar, "Design and Simulation of Cascaded H-Bridge Multilevel Inverter with STATCOM for Industrial Applications”, International Journal of Advanced Research (IJAR), Vol 5, Issue 06, pp. 82-90, June 2017.

[11] Yidan Li and Bin Wu, "A Novel DC Voltage Detection Technique in the CHB Inverter-Based STATCOM", IEEE Transactions on Power Delivery, Vol. 23, No. 3, pp. 1613-1619, July 2008.

[12] P. Adhityan, M. Rajkumar and M. R. Neetu Singh, "Improvement of Power Quality using Cascaded Multilevel Inverter in T-STATCOM based System", Proceedings of 4th IRF International Conference, ISBN: 978-93-8270298-6, Cochin, India, 19th April, 2015.

[13] Rahul Pawar, Dilip G. Borse, Sawata R. Deore, Govind Kedar, Santosh Keware, "Simulation of Cascaded H-bridge Multilevel Inverter based DSTATCOM for power quality improvement with switching modulation index", Proceeding of 7th IRF International Conference, Pune, India ISBN: 978-93-84209-09-4, 27th April 2014.

[14] Vadim I Utkin, "Sliding Mode Control Design Principles and Applications to Electric Drives", IEEE Transactions on Industrial Electronics, Vol. 40, No. 1, February 1993.

[15] Bartoszewicz A., Kaynak O. and Utkin V. I., "Special Section on Sliding Mode Control in Industrial Applications", IEEE Transactions on Industrial Electronics, Vol. 55, No.11, 2008.

[16] M. S. Chen, Y. R. Hwang and M. Tomizuka, "Sliding mode control reduced Chattering for systems with dependent uncertainties", IEEE International conference on network, Sensing and control, Taiwan, pp. 967-971, March 2004.

[17] K. D. Young, V. I. Utkin and U. Ozguner, "A control engineer's guide to sliding mode control", IEEE Transactions on Control Systems Technology, Vol. 7, pp. 328- 342, 1999.

[18] C. Edwards and S. Spurgeon, "Sliding Mode Control: Theory and Application", London Taylor and Frenis, 1999.

[19] Jun Song, Yugang Niu and Yuayuan Zou, "Finite-Time Stabilization via Sliding Mode Control", IEEE Transaction on Automatic Control, Vol. 62, No. 3, March 2017.

[20] Ligang Wu, Sudip K. Mazumder and Okyay Kaynak, "Sliding Mode Control and Observation for Complex Industrial Systems-Part I", IEEE Transaction on Industrial Electronics Vol. 64, No. 8, August 2017.

[21] Robert Priewasser, Matteo Agostinelli, Christoph Unterrieder, Stefano Marsili and Mario Huemer, "Modeling, Control and Implementation of DC-DC Converters for Variable Frequency Operation", IEEE Transactions on Power Electronics, Vol. 29, No. 1, Jan. 2014.

[22] S. S. Muley and R. M. Nagarale, "Sliding Mode Control of Boost Converter", International Journal of Emerging Technology and Advanced Engineering, Vol. 3, No. 9, 2013.

[23] Bashar Khasawneh, Maha Sabra and Mohamed A. Zohdy, "Parallel DC-DC Power Converters Sliding Mode Control with Dual Stages Design”, Journal of Power and Energy Engineering, Vol. 10, No. 2, 2014.

[24] Sunita Kumari, Sudhir Y Kumar, "Design, Analysis and Development of Inverter Topologies for Industries", Indonesian Journal of Electrical Engineering and Informatics (IJEEI), Vol. 6, No. 1, pp. 53-60, March 2018. 